\title{
Simulating the Crack Propagation Mechanism of Pre-Cracked Concrete Specimens under Shear Loading Conditions
}

\author{
H. Haeri \\ Department of Civil Engineering, Sharif University of Technology, Tehran, Iran \\ haerihadi@gmail.com, hadihaeri@ymail.com
}

УДК 539.4

\section{Моделирование механизма роста трещин в образцах из бетона с исходными трещинами при нагружении сдвигом}

\begin{abstract}
Х. Хаэри
Факультет гражданского строительства, Технологический университет Шариф, Тегеран, Иран

Исследуется механизм роста трещчин в бетонных образиах с исходными трещцнами при нагружении сдвигом. Выполнень лабораторные испьтания бетонных образиов с двумя предварительно нанесенными краевыми трещчинми. Для численного моделирования механизма роста трещчин в хрупких телах при нагружении чистым сдвигом используются концепщия разрывности перемещуений высокого порядка и специальные конечные элементы для вериины трешины для учета взаимовлияния берегов трещчин. Предложен специильный метод моделирования эффекта перекрытия берегов трешцины на процесс разрушения лигаментной зоны между двумя параллельными трещинами. На первой стадии нагружения наблюдается появление крыловидных трещин, дальнейший рост которых происходит в направлении нагружения сдвигом. Направление роста двух краевых трещин в лигаментной зоне в основном зависит от угла наклона и длины трещины, в то время как прочность при сдвиге - от типа разрушения. Анализ механизма слияния трещиин показывает, что разрушение образцов из бетона с исходными трещинами происходит по смешанной моде в случае неперекрывающихся трещин и по моде I для перекрываюшихся трещчин. Сравнение расчетных результатов с экспериментальными подтверждает высокую точность и эффективность предложенного численного метода моделирования роста трещин.
\end{abstract}

Ключевые слова: парные краевые трещины, бетонные образцы, рост трещины, испытания на чистый сдвиг, перекрывающиеся трещины.

Introduction. Presence and arrangement of discontinuities and fractures (or joints) in a rock masses or concrete structures may drastically reduce the strength of such structures. A crack may act as a nucleus of initiation and extension of new discontinuities in a brittle solid which may propagate and coalesce with other flaws. These phenomena may further reduce the strength and the stiffness of the rock materials. Recognizing, the geometrical and mechanical properties of the discontinuities and joints (or fractures) in a solid may improve the understanding of cracking mechanism and cracks coalescence in the failure process of big rock structures such as surface and underground mines, tunnels, rock slopes, etc. [1].

However, the mechanical characteristics of rock masses and concrete structures may be affected by the mechanical behaviors of the discontinuities and cracks (or joints) subjected to various loading conditions. The extension and propagation of cracks mainly depends on the size, persistence, location, spacing, opening, roughness and loading conditions $[2,3]$. 
The wing (tensile) and secondary (shear) cracks may be observed in the crack propagation process of brittle solids such as rocks, concretes and rock-like specimens. Wing cracks are usually the first cracks that are produced due to tension while secondary cracks initiate due to shear. In brittle solids, the initiation of wing cracks is favored relative to secondary cracks because of the lower toughness of these materials in tension than in shear [4].

Wing cracks are tensile cracks that mainly initiate at or near the tips of pre-existing cracks and propagate in a curved path (with increasing load) while the secondary cracks may grow after the propagation of the wing cracks (they may also initiate from the original tips of the cracks). Direct shear and compressive (indirect shear) loading conditions may both produce the secondary cracks in brittle solids. The breaking stages of the pre-cracked concrete-like specimens under shear loading have attracted the attentions of some researchers. Also many numerical studies have been carried out in this field $[5,6]$.

Savilahti et al. [7] carried out direct shear tests on plaster specimens containing non-overlapping and overlapping joints. Wong et al. [8] conducted direct shear tests on specimens made from plaster materials and natural rocks containing open non-persistent joints and investigated the shear strength and breaking process of the pre-cracked brittle solids. According to their findings, the breakage patterns of these specimens are mainly occurred due to joint separation. In addition, Gehle and Kutter [9] also studied the breakage and shear behaviors of intermittent rock joints under direct shear loading conditions. It can be concluded that the shear resistance of pre-cracked rock specimens may be affected by the crack inclination. Ghazvinian et al. $[10,11]$ and Sarfarazi et al. [12] used particle flow code $\left(\mathrm{PFC}^{2 \mathrm{D}}\right)$ to study the effect of non-overlapping and overlapping joints on the breakage behavior of a rock bridge under direct shear tests. They compared the numerical simulations and experimental tests and confirmed that the simulated breaking paths within the specimens are similar to those obtained by experiments.

Some experimental works have been devoted to study the crack initiation, propagation, interaction and eventual coalescence of the pre-existing cracks inspecimens prepared from various brittle materials, including natural rocks and concrete-like materials under compressive loading conditions [13-26].

Several numerical methods have also been used to simulate the crack propagation process in brittle solids under various loading conditions, e.g., finite element method (FEM), boundary element method (BEM), discrete element method (DEM), etc. [27-30]. Based on the numerical and analytical methods, some computer codes were proposed to model the breaking mechanism of brittle materials such as geo-materials, e.g., FROCK code [19], Rock Failure Process Analysis $\left(\mathrm{RFPA}^{2 \mathrm{D}}\right)$ code [31], 2D Particle Flow Code $\left(\mathrm{PFC}^{2 \mathrm{D}}\right)$ [10-12].

Mainly, three classical fracture initiation criteria were used to study the crack propagation mechanism of brittle materials based on the linear elastic fracture mechanics (LEFM) concepts: (i) maximum tangential stress criterion ( $\sigma$-criterion) [32], (ii) maximum energy release rate criterion ( $G$-criterion) [33], and (iii) minimum energy density criterion ( $S$-criterion) [34]. $F$-criterion which is a modification of the maximum energy release rate criterion has been proposed by Shen and Stephansson [35]. It may also be used to study the fracturing behavior of brittle solids [31-42].

In this study, single and double edge cracked concrete specimens were specially prepared from a proper mixture of portland pozzolana cement (PPC), sand and water in a concrete laboratory and tested under shear loading. The crack propagation mechanism of these pre-cracked concrete specimens is experimentally investigated by carrying out some indirect shear tests. The same specimens are numerically simulated by a modified higher order displacement discontinuity method. A computer code is prepared by using a cubic variation of displacement discontinuities with four equal subelements and treating the crack tips by using some special crack tip elements near the crack ends. 
The proposed computer code estimates the mode I and mode II stress intensity factors (based on the LEFM concepts) and the $\sigma$-criterion (which is implemented in this code) can predict the possible crack propagation and the crack initiation direction. This numerical scheme may be regarded as a mesh reducing dual boundary element method [43, 44] for the crack analysis (in two dimensions) where the cracks are discretized as two overlapping straight lines (not as two separate lines as considered in the conventional dual boundary element method).

In this study, the cracks coalescence mechanism for the double edge cracked specimens indicated that the jointed specimen break in the mixed mode in the case of non-overlapping joints configuration and in the tensile mode for the overlapping joints form. The effects of non-overlapping and overlapping cracks configurations on the final fracturing path in the bridge areas (in between the two edge cracks) are also studied. Finally, a comparison is accomplished between the results of the present numerical analysis with those cited in the literature. These comparisons showed that the numerical results are well fitted with experimental and numerical results and approve the accuracy and efficiency of the proposed numerical method in the study of the breaking process under direct shear loading conditions.

1. Shear Fracturing Process. Consider a body of box shape with an arbitrary size of a crack, subjected to arbitrary shear loading as shown in Fig. 1. When a crack is subjected to pure shear loading, the normalized mode I stress intensity factor $K_{\mathrm{I}}(\theta) /(\tau \sqrt{\pi a})$ is reached to its maximum value at a propagation angle $\theta\left(\theta=75.50^{\circ}\right)$, and at propagation angles $90^{\circ}<\theta<-40^{\circ}$ its value may be larger than the normalized mode II stress intensity factor $K_{\mathrm{II}}(\theta) /(\tau \sqrt{\pi a})$.

The compressive stress applied on the original crack plan may not be sufficient to reduce or eliminate the high tension stress near the crack tip (i.e., at $\theta>\mid 40^{\circ}$ ) resulting in a mode I failure.

Since the singularities of the tensile (wing) stresses near the crack ends may reduce their accuracy, low normal compressive stress were applied to the surface of original crack. Therefore, a shear fracture model as shown in Fig. 1 is proposed here.

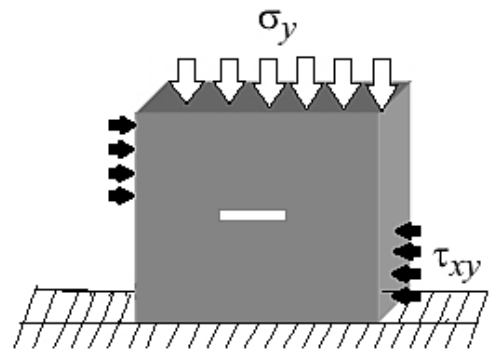

Fig. 1. Loading condition for shear box test.

Figure 2 illustrates the loading mode and crack tip stress for shear box test. The forces in Cartesian coordinates are obtained as [45]:

$$
p_{x}=p \sin \alpha, \quad p_{y}=p \cos \alpha .
$$

These forces produce the shear and compressive stresses $\left(\tau_{x y}\right.$ and $\left.\sigma_{y}\right)$, respectively. The $\tau_{x y}$ and $\sigma_{y}$ on original crack plane can express as [46]:

$$
\sigma_{y}=-\frac{p}{A} \cos \alpha, \quad \tau_{x y}=\frac{p}{A} \sin \alpha .
$$




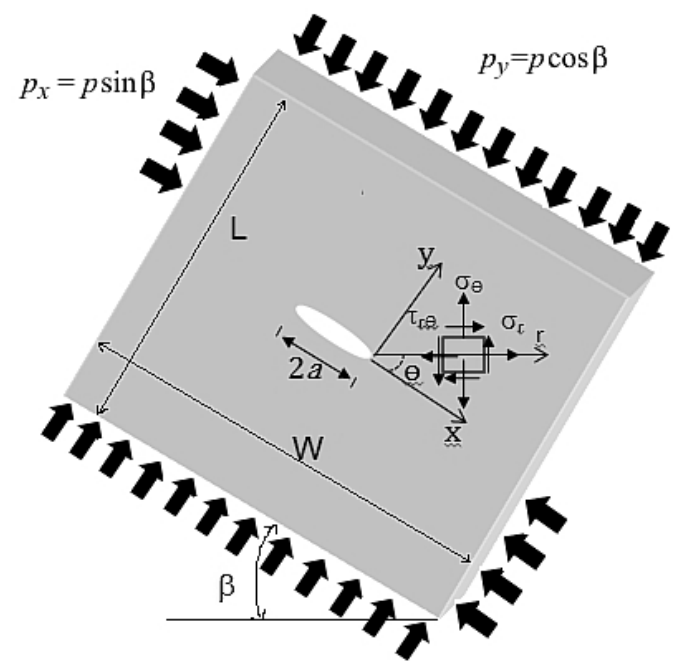

Fig. 2. Loading and stress mode at the tip of crack.

Based on the LEFM principles, the mode I and mode II stress intensity factors $K_{\mathrm{I}}^{\prime}(\theta)$ and $K_{\mathrm{II}}^{\prime}(\theta)$ (expressed in $\mathrm{MPa} \cdot \mathrm{m}^{1 / 2}$ ) can be written in terms of the normal and shear stresses $[46,47]$ obtained for the last special crack tip element as

$$
K_{\mathrm{I}}^{\prime}(\theta)=-\frac{p}{A} \cos \alpha \sqrt{\pi a}, \quad K_{\mathrm{II}}^{\prime}(\theta)=\frac{p}{A} \sin \alpha \sqrt{\pi a} .
$$

The shear $\sigma_{\theta}^{\prime}$ and tangent stresses $\tau_{r \theta}$ in polar coordinates at the tip of a crack, or a measure of the crack tip elastic stress field are obtained as

$$
\begin{gathered}
\sigma_{\theta}^{\prime}=\frac{K_{\mathrm{I}}^{\prime}(\theta)}{\sqrt{2 \pi r}} \cos ^{3} \frac{\theta}{2}+\frac{K_{\mathrm{II}}(\theta)}{\sqrt{2 \pi r}}\left(3 \sin \frac{\theta}{2} \cos ^{2} \frac{\theta}{2}\right), \\
\tau_{r \theta}=\frac{K_{\mathrm{I}}^{\prime}(\theta)}{\sqrt{2 \pi r}} \sin \frac{\theta}{2} \cos ^{2} \frac{\theta}{2}+\frac{K_{\mathrm{II}}(\theta)}{\sqrt{2 \pi r}} \cos \frac{\theta}{2}\left(1-3 \sin ^{2} \frac{\theta}{2}\right) .
\end{gathered}
$$

The final results for a mixed mode I and II are given here for completeness

$$
\begin{aligned}
& K_{\mathrm{I}}(\theta)=K_{\mathrm{I}}^{\prime}(\theta) \cos ^{3} \frac{\theta}{2}+K_{\mathrm{II}}(\theta)\left(-3 \sin \frac{\theta}{2} \cos ^{2} \frac{\theta}{2}\right)+K_{\mathrm{II}}^{\prime \prime}(\theta) \cos ^{2} \frac{\theta}{2}, \\
& K_{\mathrm{II}}(\theta)=K_{\mathrm{I}}^{\prime}(\theta) \sin \frac{\theta}{2} \cos ^{2} \frac{\theta}{2}+K_{\mathrm{II}}(\theta) \cos \frac{\theta}{2}\left(1-3 \sin ^{2} \frac{\theta}{2}\right) .
\end{aligned}
$$

2. Specimen Simulations and Testing. Various numerical direct shear tests were conducted on concrete-like specimens containing double edge cracks. These specimens with different ligament angles (the ligament angle is the counterclockwise angle between the ligament length and shear axis and crack lengths are prepared.

Two non-overlapping/overlapping cracks with different locations are shown in Figs. 3 and 4 . The crack geometries are defined by two parameters namely $\psi$ and $b$ showing the ligament angle and length of the two cracks, respectively. For different ligament angles, the lengths of edge cracks are different. 


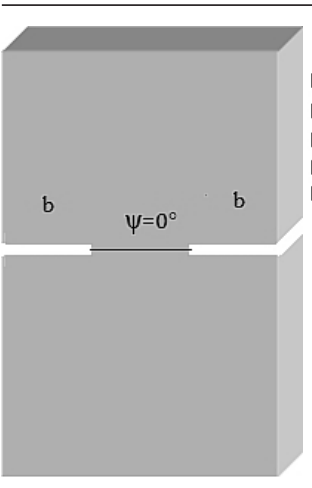

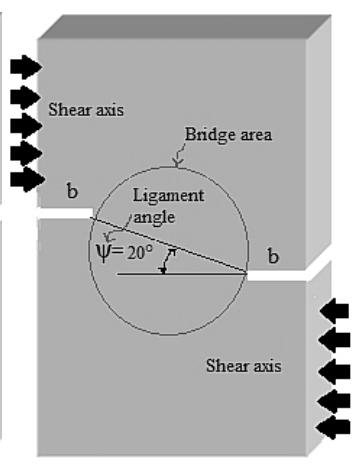

$\mathrm{b}$

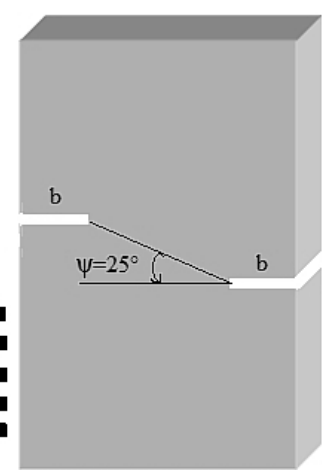

C

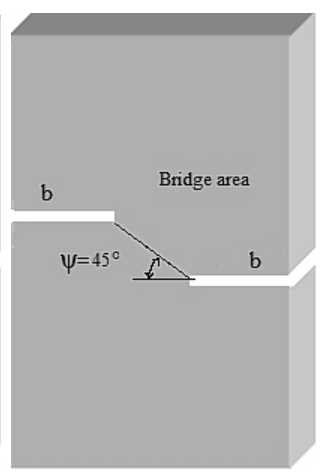

d

Fig. 3. Non-overlapped crack geometries with different ligament angles $\psi$ : (a) $\psi=0$; (b) $\psi=20^{\circ}$; (c) $\psi=25^{\circ}$; (d) $\psi=45^{\circ}$.

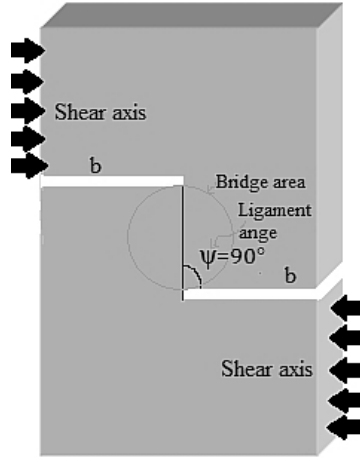

a

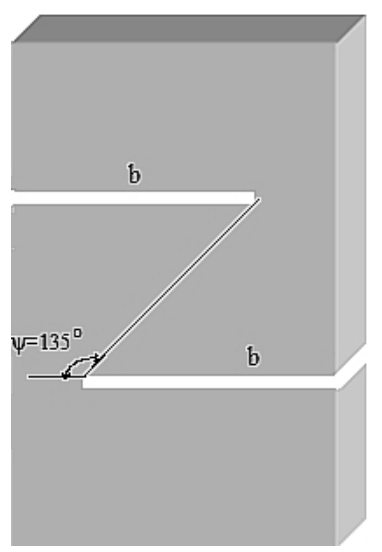

$\mathrm{e}$

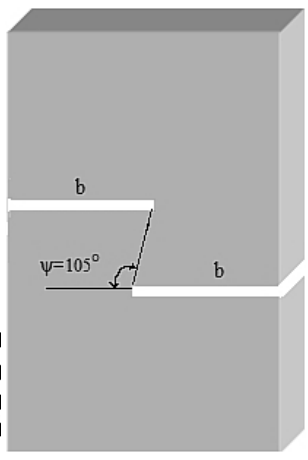

$\mathrm{b}$

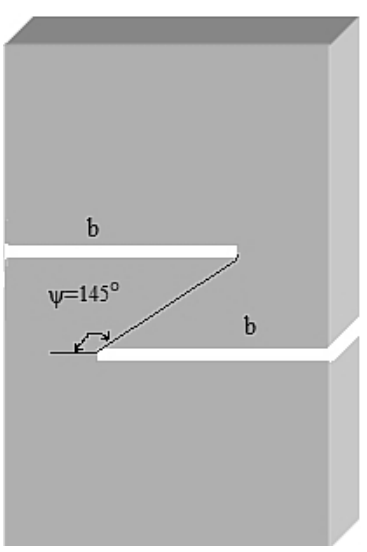

$\mathrm{f}$

$\mathrm{c}$
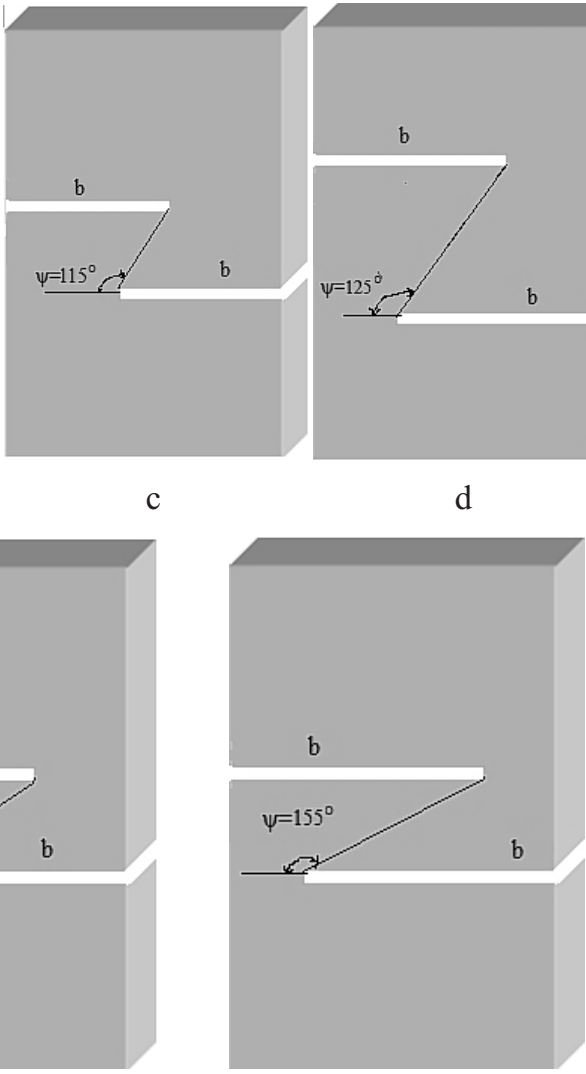

$\mathrm{g}$

Fig. 4. Overlapped crack geometries with different ligament angles $\psi$ : (a) $\psi=90^{\circ}$; (b) $\psi=105^{\circ}$; (c) $\psi=115^{\circ}$; (d) $\psi=125^{\circ}$; (e) $\psi=135^{\circ}$; (f) $\psi=145^{\circ}$; (g) $\psi=155^{\circ}$.

Ligament angle $(\psi): 0,20,25,45,90,105,115,125,135,145$, and $155^{\circ}$.

The mechanical properties of the prepared concrete-like shear specimens are: compressive strength $\sigma_{c}=28 \mathrm{MPa}$, the Young modulus $E=15 \mathrm{GPa}$, Brazilian tensile strength $\sigma_{t}=3.81 \mathrm{MPa}$, and Poisson's ratio $v=0.21$. 
3. Numerical Simulation. A displacement based version of the indirect boundary element method known as displacement discontinuity method (DDM) originally proposed by Crouch [48] for the solution of elastostatic problems in solid mechanics is used in this study $[39,49-51]$.

3.1. Displacement Discontinuity Method Using Cubic DD Elements. In this research, a higher accuracy of the displacement discontinuities along the boundary of the problem is obtained by using cubic displacement discontinuity (DD) elements is used. A cubic DD element, $D_{k}(\varepsilon)$ is divided into four equal subelements that each subelement contains a central node for which the nodal DD van be calculate two fundamental variables of each element (the opening displacement discontinuity $D_{y}$ and sliding displacement discontinuity $\left.D_{x}\right)[52]$

$$
D_{k}(\varepsilon)=\sum_{i=1}^{4} \Pi_{i}(\varepsilon) D_{k}^{i}, \quad k=x, y,
$$

where $D_{k}^{1}$ (i.e., $D_{x}^{1}$ and $D_{y}^{1}$ ), $D_{k}^{2}$ (i.e., $D_{x}^{2}$ and $D_{y}^{2}$ ), $D_{k}^{3}$ (i.e., $D_{x}^{3}$ and $D_{y}^{3}$ ), and $D_{k}^{4}$ (i.e., $D_{x}^{4}$ and $D_{y}^{4}$ ), are the cubic nodal displacement discontinuities and,

$$
\begin{aligned}
& \Pi_{1}(\varepsilon)=-\left(3 a_{1}^{3}-a_{1}^{2} \varepsilon-3 a_{1} \varepsilon^{2}+\varepsilon^{3}\right) /\left(48 a_{1}^{3}\right), \\
& \Pi_{2}(\varepsilon)=\left(9 a_{1}^{3}-9 a_{1}^{2} \varepsilon-a_{1} \varepsilon^{2}-\varepsilon^{3}\right) /\left(16 a_{1}^{3}\right), \\
& \Pi_{3}(\varepsilon)=\left(9 a_{1}^{3}+9 a_{1}^{2} \varepsilon-a_{1} \varepsilon^{2}-\varepsilon^{3}\right) /\left(16 a_{1}^{3}\right), \\
& \Pi_{4}(\varepsilon)=-\left(3 a_{1}^{3}+a_{1}^{2} \varepsilon-3 a_{1} \varepsilon^{2}-\varepsilon^{3}\right) /\left(48 a_{1}^{3}\right),
\end{aligned}
$$

are the cubic collocation shape functions using $a_{1}=a_{2}=a_{3}=a_{4}$. As shown in Fig. 5, a cubic DD element is divided into three equal subelements (each subelement contains a central node for which the nodal displacement discontinuities are evaluated numerically).

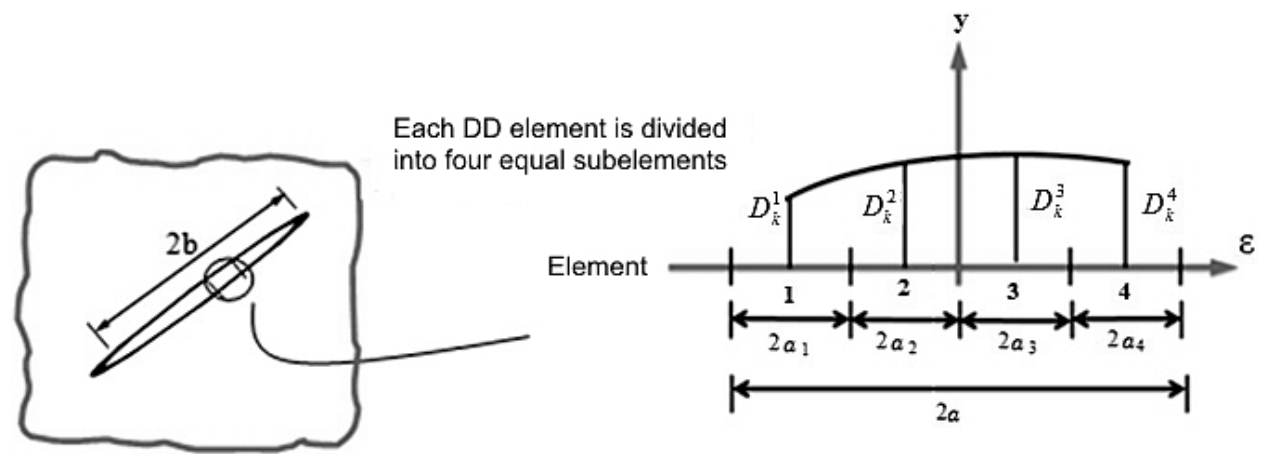

Fig. 5. Cubic shape function showing the variation of higher order displacement discontinuities along an ordinary boundary element.

The potential functions $f(x, y)$ and $g(x, y)$ for the cubic case can be find from

$$
\begin{aligned}
& f(x, y)=\frac{-1}{4 \pi(1-v)} \sum_{i=1}^{4} D_{x}^{i} F_{i}\left(I_{0}, I_{1}, I_{2}\right), \\
& g(x, y)=\frac{-1}{4 \pi(1-v)} \sum_{i=1}^{4} D_{y}^{i} F_{i}\left(I_{0}, I_{1}, I_{2}\right),
\end{aligned}
$$


in which the common function $F_{i}$ is defined as

$$
F_{i}\left(I_{0}, I_{1}, I_{2}, I_{3}\right)=\int N_{i}(\varepsilon) \ln \left[(x-\varepsilon)^{2}+y^{2}\right]^{1 / 2} d \varepsilon, \quad i=1, \ldots, 4,
$$

where the integrals $I_{0}, I_{1}, I_{2}$, and $I_{3}$ are expressed as follows:

$$
\begin{aligned}
& I_{0}(x, y)=\int_{-a}^{a} \ln \left[(x-\varepsilon)^{2}+y^{2}\right]^{1 / 2} d \varepsilon, \\
& I_{1}(x, y)=\int_{-a}^{a} \varepsilon \ln \left[(x-\varepsilon)^{2}+y^{2}\right]^{1 / 2} d \varepsilon, \\
& I_{2}(x, y)=\int_{-a}^{a} \varepsilon^{2} \ln \left[(x-\varepsilon)^{2}+y^{2}\right]^{1 / 2} d \varepsilon, \\
& I_{3}(x, y)=\int_{-a}^{a} \varepsilon^{3} \ln \left[(x-\varepsilon)^{2}+y^{2}\right]^{1 / 2} d \varepsilon .
\end{aligned}
$$

The singularities of the stresses and displacements near the crack ends may reduce their accuracies, special crack tip elements can be effectively used to increase the accuracy of the DDs near the crack tips [36]. As shown in Fig. 6, the DD variations for three nodes

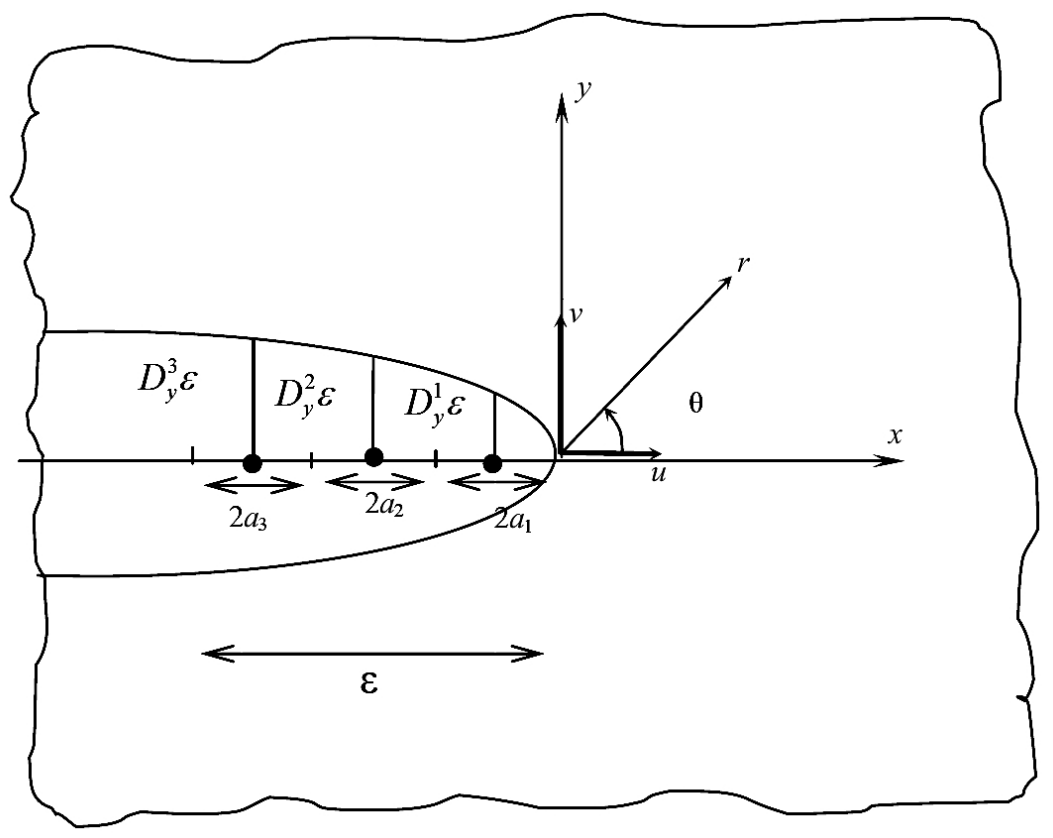

Fig. 6. Special crack tip element with three equal subelements.

can be formulated using a special crack tip element containing three nodes (or having three special crack tip subelements),

$$
D_{k}(\varepsilon)=\left[\Gamma_{C 1}(\varepsilon)\right] D_{k}^{1}(a)+\left[\Gamma_{C 2}(\varepsilon)\right] D_{k}^{2}(a)+\left[\Gamma_{C 3}(\varepsilon)\right] D_{k}^{3}(a), \quad k=x, y,
$$


where each crack tip element has a length $a_{1}=a_{2}=a_{3}=a_{4}$. Considering a crack tip element with the three equal subelements $\left(a_{1}=a_{2}=a_{3}\right)$, the shape functions $\Gamma_{C 1}(\varepsilon)$, $\Gamma_{C 2}(\varepsilon)$, and $\Gamma_{C 3}(\varepsilon)$ can be obtained as

$$
\begin{gathered}
\Gamma_{C 1}(\varepsilon)=\frac{15 \varepsilon^{1 / 2}}{8 a_{1}^{1 / 2}}-\frac{\varepsilon^{3 / 2}}{a_{1}^{3 / 2}}+\frac{\varepsilon^{5 / 2}}{8 a_{1}^{5 / 2}}, \\
\Gamma_{C 2}(\varepsilon)=\frac{-5 \varepsilon^{1 / 2}}{8 a_{1}^{1 / 2}}+\frac{3 \varepsilon^{3 / 2}}{2 \sqrt{3} a_{1}^{3 / 2}}-\frac{\varepsilon^{5 / 2}}{4 \sqrt{3} a_{1}^{5 / 2}}, \\
\Gamma_{C 3}(\varepsilon)=\frac{3 \varepsilon^{1 / 2}}{8 \sqrt{5} a_{1}^{1 / 2}}-\frac{\varepsilon^{3 / 2}}{2 \sqrt{5} a_{1}^{3 / 2}}+\frac{\varepsilon^{5 / 2}}{8 \sqrt{5} a_{1}^{5 / 2}}, \\
F_{C}(x, y)=\frac{-1}{4 \pi(1-v)} \int_{-a}^{a} D_{k}(\varepsilon) \ln \left[(x-\varepsilon)^{2}+y^{2}\right]^{1 / 2} d \varepsilon, \quad k=x, y .
\end{gathered}
$$

Inserting the common displacement discontinuity function $D_{k}(\varepsilon)$ [Eq. (12)] in Eq. (14) gives

$$
\begin{aligned}
F_{C}(x, y) & =\frac{-1}{4 \pi(1-v)}\left\{\left[\int_{-a}^{a} \Gamma_{C 1}(\varepsilon) \ln \left[(x-\varepsilon)^{2}+y^{2}\right]^{1 / 2} d \varepsilon\right] D_{k}^{1}+\right. \\
& +\left[\int_{-a}^{a} \Gamma_{C 2}(\varepsilon) \ln \left[(x-\varepsilon)^{2}+y^{2}\right]^{1 / 2} d \varepsilon\right] D_{k}^{2}+ \\
+ & {\left.\left[\int_{-a}^{a} \Gamma_{C 3}(\varepsilon) \ln \left[(x-\varepsilon)^{2}+y^{2}\right]^{1 / 2} d \varepsilon\right] D_{k}^{3}\right\}, \quad k=x, y . }
\end{aligned}
$$

Inserting the shape functions $\Gamma_{C 1}(\varepsilon), \Gamma_{C 2}(\varepsilon)$, and $\Gamma_{C 3}(\varepsilon)$ in Eq. (15) after some manipulations and rearrangements the following three special integrals are deduced:

$$
\begin{aligned}
& I_{C 1}(x, y)=\int_{-a}^{a} \varepsilon^{1 / 2} \ln \left[(x-\varepsilon)^{2}+y^{2}\right]^{1 / 2} d \varepsilon, \\
& I_{C 2}(x, y)=\int_{-a}^{a} \varepsilon^{3 / 2} \ln \left[(x-\varepsilon)^{2}+y^{2}\right]^{1 / 2} d \varepsilon, \\
& I_{C 3}(x, y)=\int_{-a}^{a} \varepsilon^{5 / 2} \ln \left[(x-\varepsilon)^{2}+y^{2}\right]^{1 / 2} d \varepsilon .
\end{aligned}
$$

Based on the LEFM principles, the mode I and mode II stress intensity factors $K_{\mathrm{I}}$ and $K_{\text {II }}$ (expressed in $\mathrm{MPa} \cdot \mathrm{m}^{1 / 2}$ ) can be written in terms of the normal and shear displacement discontinuities [47] obtained for the last special crack tip element as

$$
K_{\mathrm{I}}=\frac{\mu}{4(1-v)}\left(\frac{2 \pi}{a_{1}}\right)^{1 / 2} D_{y}\left(a_{1}\right) \quad \text { and } \quad K_{\mathrm{II}}=\frac{\mu}{4(1-v)}\left(\frac{2 \pi}{a_{1}}\right)^{1 / 2} D_{x}\left(a_{1}\right)
$$

where $\mu$ is the shear modulus and $v$ is Poisson's ratio of the brittle material. 
3.2. Numerical Simulation of the Edge Cracked Specimens. A modified higher order displacement discontinuity method based on the versatile boundary element method is used for the numerical simulation of the double edge cracked specimens proposed in this research to study the cracks coalescence and final breakage path of a bridge area under shear box loading conditions. The LEFM approach based on the concept of mode I and mode II stress intensity factors proposed by Irwin [53] is implemented in the boundary element code and the maximum tangential stress criterion given by Erdogan and Sih [32] is used in a stepwise procedure to estimate the propagation path of the propagating wing cracks.

Since the experimental analysis of crack propagation is somewhat time-consuming, expensive, difficult and complex, some more numerical simulations of crack propagation process are also accomplished by boundary element method in this study.

The numerical simulation is done for several cases with different ligament angles and ligament lengths as schematically shown in Figs. 3 and 4.

Figures 7-9 present the results of numerical simulation considering different ligament angles (i.e., at angles $\psi=0,20,25,45,105,115,125,135,145$, and $155^{\circ}$ ). Comparing Figs. 7-9, it can be concluded that the final breakage path of the pre-cracked specimens may be affected by ligament angles and the lengths of edge crack.

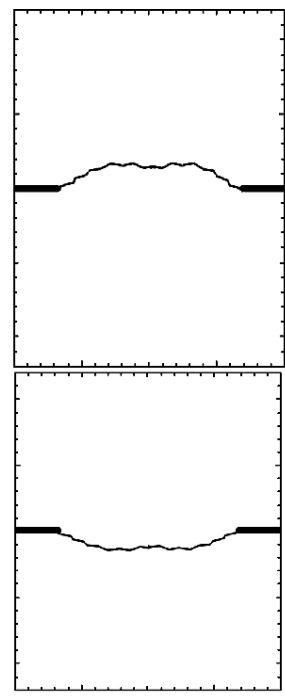

a

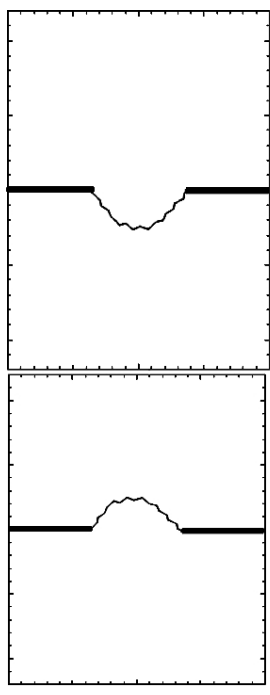

b

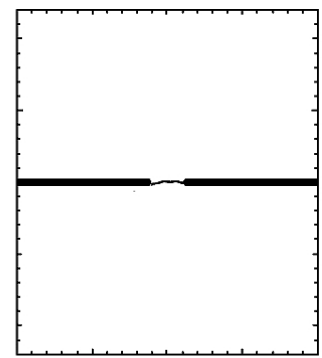

$\mathrm{c}$

Fig. 7. The breakage paths of non-overlapped cracks for $\psi=0$ with different lengths $b$ : (a) $b=$ $=26.2 \mathrm{~mm}$; (b) $b=48.7 \mathrm{~mm}$; (c) $b=67.5 \mathrm{~mm}$.

3.3. Effect of Crack Overlapping on the Fracturing Behavior of Bridge Areas. The cracks coalescence and breakage paths of double edge cracked specimens with nonoverlapping and overlapping cracks are described in this section.

3.3.1. Breakage Paths of Specimens Containing Non-Overlapped Cracks. In the current simulations, the wing cracks are instantaneously initiated quasi-statically (Figs. 7-9). The development and coalescence of wing cracks in the bridge area (the area in between the two cracks in the specimens containing double edge cracks) may be the main cause of the breakage paths in rock-like disc specimens.

Figures 7 and 8 illustrate the breakage paths of non-overlapping cracks for cases $\psi=0,20,25,45$, and $90^{\circ}$. Three specimens with different crack lengths for $\psi=0$ are modeled as shown in Fig. 7. 


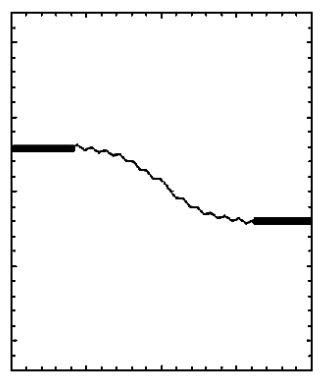

a

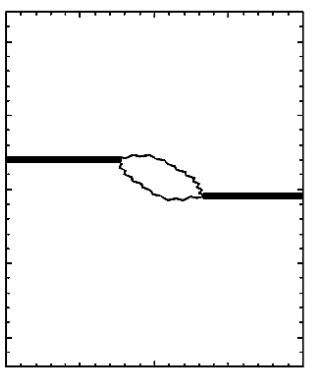

b

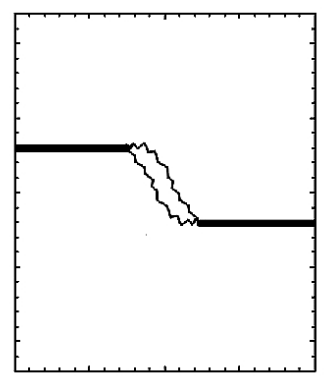

C

Fig. 8. Breakage paths of non-overlapped cracks for $\psi=20^{\circ}$ (a) $\psi=25^{\circ}$ (b), and $\psi=45^{\circ}$ (c).
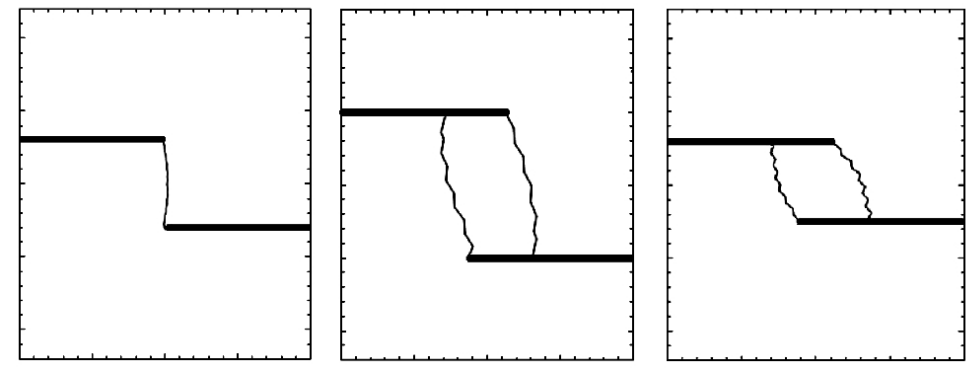

b
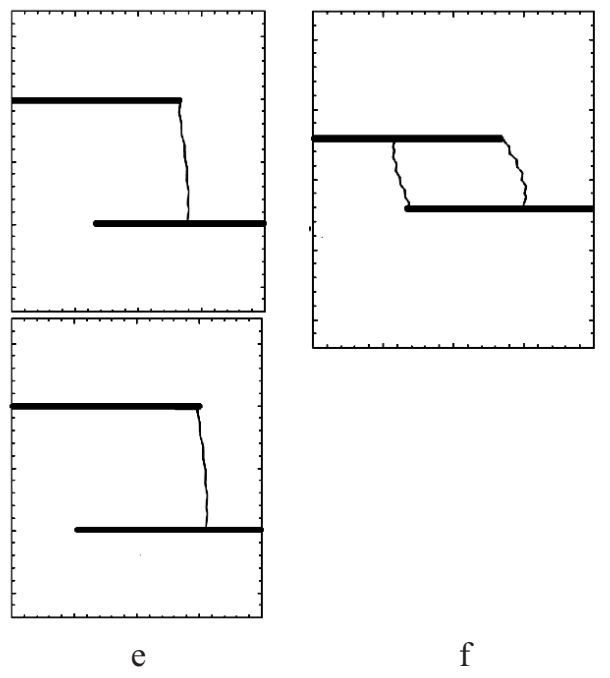

e

$\mathrm{c}$

$\mathrm{f}$

$\mathrm{g}$

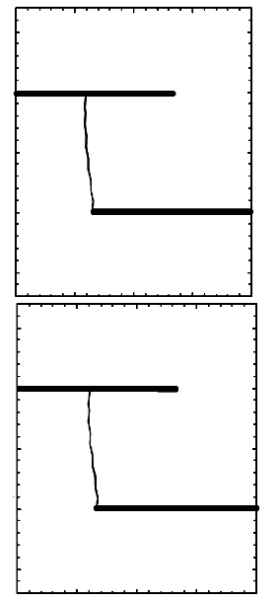

d

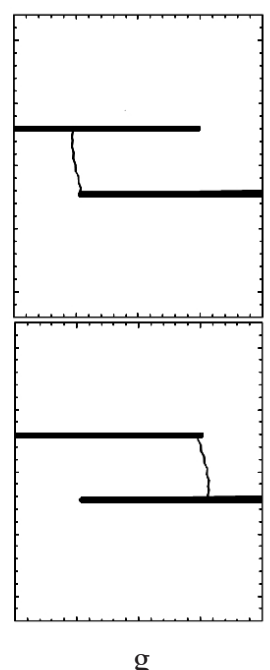

Fig. 9. The breakage paths of overlapped cracks: (a) $\psi=90^{\circ}$; (b) $\psi=105^{\circ}$; (c) $\psi=115^{\circ}$; (d) $\psi=$ $=125^{\circ}$; (e) $\psi=135^{\circ}$; (f) $\psi=145^{\circ}$; (g) $\psi=155^{\circ}$.

For $\psi=0$, when the crack lengths are $b=26.2$ and $48.7 \mathrm{~mm}$ (Fig. 7a, b), the wing cracks initiated at the tips of the both cracks and then the cracks coalesced with each other 
at the propagating crack tips in the bridge area, but for the case shown in Fig. 7c (for $\psi=0$ ) with the cracks length $b=67.5 \mathrm{~mm}$, the cracks may first start to initiate at the tips of cracks and then the specimen may fail in the direction of the original cracks plane.

It should be noted that for the case shown in Fig. 8a (for $\psi=20^{\circ}$ ) first the wing cracks initiated at the tips of cracks and then the cracks coalesced with each other at the propagating crack tips in the bridge area.

For cases shown in Fig. 8b, c (for $\psi=25$ and $45^{\circ}$ ), the wing cracks initiated at the tip of the cracks and propagated in a curved path until they coalesced with the tip of the other crack, and also, no coalescence have occurred at the tips of the propagating cracks.

3.3.2. Breakage Paths of Specimens Containing Overlapped Cracks. Figure 9a-g illustrate the fracturing paths of overlapped cracks for cases $\psi=90,105,115,125,135$, 145 , and $155^{\circ}$.

For case shown in Fig. 9a (for $\psi=90^{\circ}$ ) the wing cracks initiated and continued their growth in a direction (approximately) vertical to the direction of maximum shear force and coalesced with each other at the propagating crack tips in the bridge area. In this breakage mode, the specimen may fail with a single breakage surface.

For case shown in Fig. 9b, c, and $\mathrm{f}$ (for $\psi=105,115$, and $145^{\circ}$ ), the wing cracks initiate at the cracks and propagated to that of the other crack wall.

It should be noted that for the case shown in Fig. 9d, e, and g (for $\psi=125,135$, and $\left.155^{\circ}\right)$, the cracks initiated at the tip of upper/lower crack first and then the specimen might fail due to crack propagation process starting from the tip of upper/lower and also, no coalescence might occur at the tips of cracks.

4. Discussion. The crack propagation process in concrete samples has been studied by several researches using the edge cracked problem under shear loading.

Recently Sarfarazi et al. [12] have been experimentally and numerically investigated. The effect of crack overlap on the final breakage behavior of a bridge area in the shear box test for different specimens, the lengths of edge joints are different; for the same specimen, the lengths of those two joints are the same. The crack lengths $b$ are 52.5, 66.8, 75, or $78.8 \mathrm{~mm}$ which are associated with ligament angles $\psi=0,25,90$, and $115^{\circ}$ for double edge cracked concrete-like samples (Fig. 10). They have used $\mathrm{PFC}^{2 \mathrm{D}}$ code (a discrete element approach based on finite difference method) to conduct a number of numerical simulations to reproduce their experimental works on double edge cracked samples. Table 1 shows the mechanical properties of concrete-like specimens.

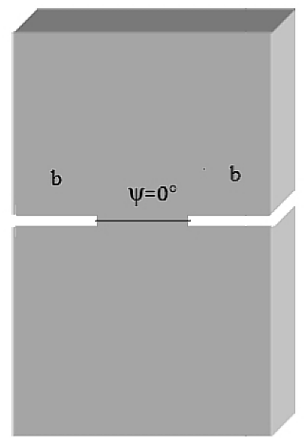

a

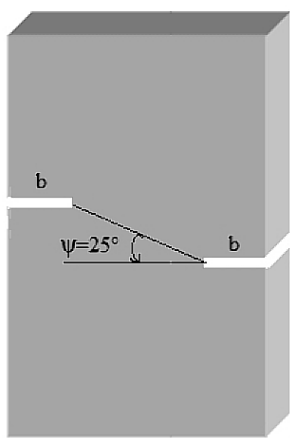

b

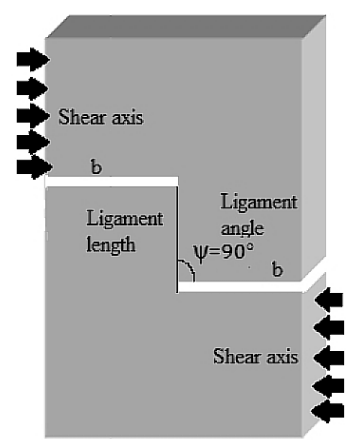

c

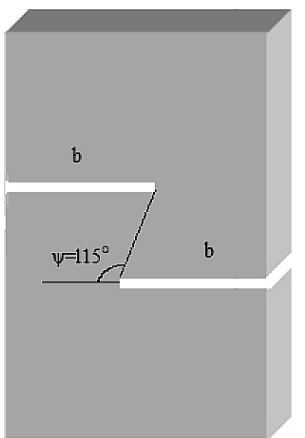

d

Fig. 10. Non-overlapped (a, b) and overlapped (c, d) crack geometries with different ligament angles $\psi$ : (a) $\psi=0$; (b) $\psi=25^{\circ}$; (c) $\psi=90^{\circ}$; (d) $\psi=115^{\circ}$.

Figures 11 and 12 illustrate the Sarfarazi et al. [12] experimental works and $\mathrm{PFC}^{2 \mathrm{D}}$ simulations of the crack propagating paths in concrete-like specimens with variable ligament angles $\psi=0,25,90$, and $115^{\circ}$, respectively [12]. 
T a b 1 e 1

Mechanical Properties of a Concrete-Like Specimen [12]

\begin{tabular}{||l|c|c|c||}
\hline \multicolumn{1}{|c|}{ Description } & Parameter & Value & Unit \\
\hline Crack length & $b$ & - & $\mathrm{mm}$ \\
\hline Average uniaxial compressive strength & $\sigma_{c}$ & 6.6 & $\mathrm{MPa}$ \\
\hline Density & $\gamma$ & 1,200 & $\mathrm{~kg} / \mathrm{m}^{3}$ \\
\hline Average Brazilian tensile strength & $\sigma_{t}$ & 1 & $\mathrm{MPa}$ \\
\hline Average Young's modulus in compression & $E$ & 5 & $\mathrm{GPa}$ \\
\hline Cohesion & - & 2.2 & $\mathrm{MPa}$ \\
\hline Internal angle of friction & - & 20.4 & $\mathrm{deg}$ \\
\hline
\end{tabular}

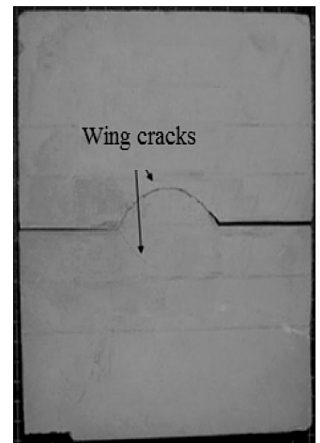

a

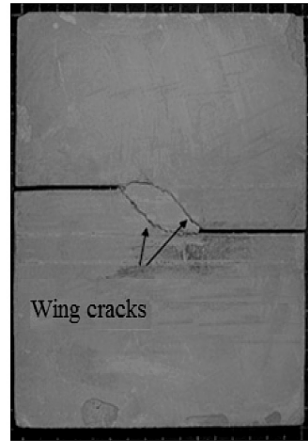

b

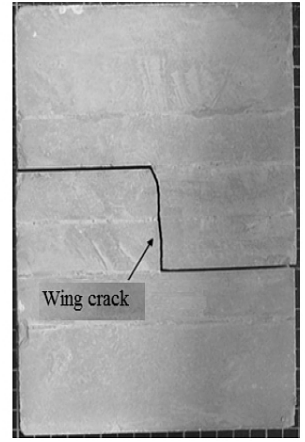

c

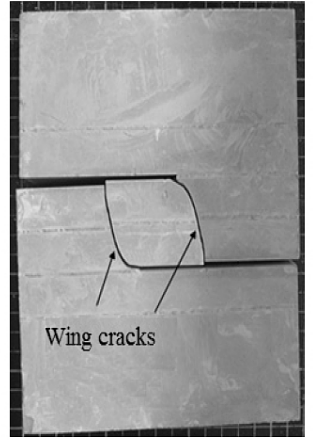

d

Fig. 11. The crack propagation paths in concrete-like specimens with different ligament angles $\psi=0$ (a), 25 (b), 90 (c), and $115^{\circ}$ (d) [12].

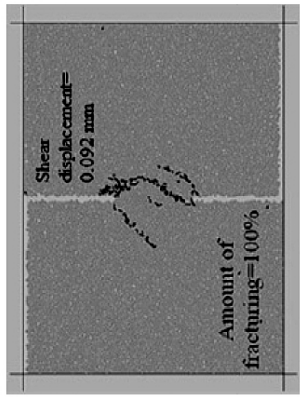

a

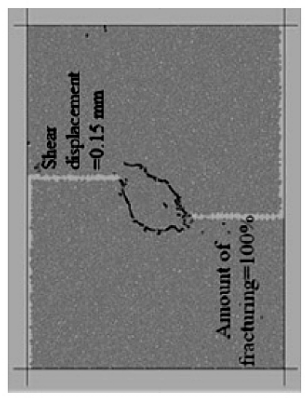

b

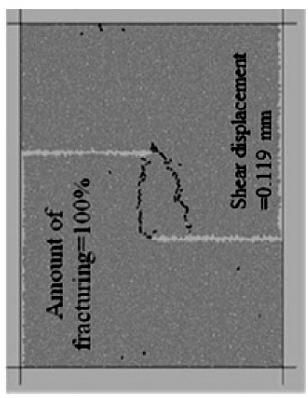

$\mathrm{c}$

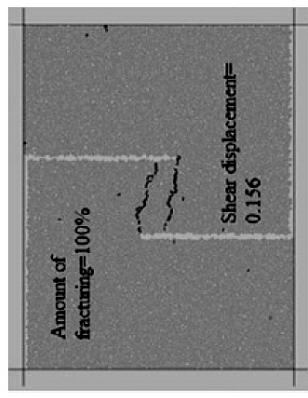

d

Fig. 12. $\mathrm{PFC}^{2 \mathrm{D}}$ simulation of the propagating paths in concrete-like specimens with variable ligament angles $\psi=0$ (a), 25 (b), 90 (c), and $115^{\circ}$ (d) [12].

The crack propagation process of concrete like specimens has also been numerically studied by using the higher order boundary element method proposed in this study. The numerical results obtained by the boundary element simulation of the propagating paths in the edge cracked specimens are shown in Fig. 13. The numerically simulated crack propagation paths shown in Fig. 13 were in good agreement with the experimental results given by Sarfarazi et al. [12] in Fig. 11. Comparing the results graphically shown in Figs. 12 and 13 with the experimental works in Fig. 11 clearly demonstrate the accuracy, validity 


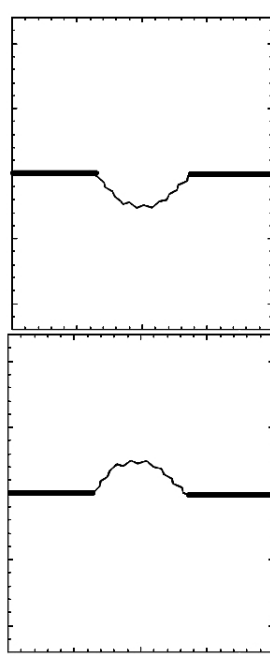

a
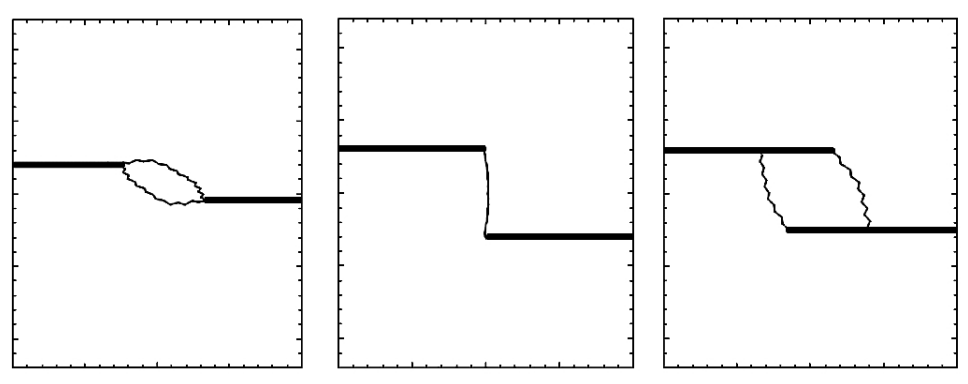

b d

Fig. 13. Boundary element simulation of the crack propagation process in double edge cracked specimens with variable ligament angles $\psi=0$ (a), 25 (b), 90 (c), and $115^{\circ}$ (d).

and superiority of the boundary element results compared to those obtained by $\mathrm{PFC}^{2 \mathrm{D}}$ code (given in Fig. 12). The boundary element code is much faster and it is quite easy to work with it because the boundary element method essentially reduces one dimension of the problem and alternatively reduces the mesh size sharply and makes the discretization of the problem simpler and quicker.

Conclusions. The mechanism of crack propagation in brittle solids under shearing mode has been studied by comprehensive experimental and numerical studies in the recent years. This mechanism is a complicated process and further research may be devoted to investigate the crack propagation, cracks coalescence and final breakage paths of a bridge area under direct shear loading condition (the condition of shear box test).

A modified higher order displacement discontinuity method, (which is a category of the broad boundary element method) was especially developed to simulate the mechanism of crack propagation and cracks coalescence in the specimens and in the bridge areas of the edge cracks. The linear elastic fracture mechanics theory based on mode I and mode II stress intensity factors is used in the numerical simulation.

Effects of ligament angle and crack lengths in the bridge area on the fracturing process of edge cracked specimens containing non-overlapping and overlapping cracks have been modeled. It has been shown that the breaking of edge cracked specimens occur mainly by the propagation of wing cracks emanating from the tips of the two pre-existing cracks.

The numerical models well illustrate the production of the wing cracks and the cracks propagation paths produced by the coalescence phenomenon of the non-overlapping and overlapping cracks in the bridge area. In this study, it has been shown that there is a good agreement between the corresponding numerical and experimental results which enables one to clearly understand the fracturing mechanism of concrete like specimens containing edge cracks.

It has also been shown that the specimens containing overlapping cracks with high ligament angles may fail at a single fracturing surface. This failure pattern is highly dependent on joint overlapping. In non-overlapping cracks with lower ligament angles, the cracks are initiated from both two cracks tips and the elliptical breaking surface may occur in the models. 
Р езюме

Досліджується механізм росту тріщин у бетонних зразках із початковими тріщинами при навантаженні зсувом. Виконано лабораторні випробування бетонних зразків із двома попередньо нанесеними крайовими тріщинами. Для чисельного моделювання механізму росту тріщин у крихких тілах при навантаженні чистим зсувом використовуються концепція розривності переміщень високого порядку і спеціальні скінченні елементи для вершини тріщини для урахування взаємовпливу берегів тріщин. Запропоновано спеціальний метод моделювання ефекту перекриття берегів тріщини на процес руйнування лігаментної зони між двома паралельними тріщинами. На першій стадії навантаження виникають криловидні тріщини, які в подальшому ростуть у напрямку навантаження зсувом. Напрямок росту двох крайових тріщин у лігаментній зоні в основному залежить від кута нахилу і довжини тріщини, в той час як міцність при зсуві - від типу руйнування. Аналіз механізму злиття тріщин показує, що руйнування зразків із бетону з початковими тріщинами відбувається по змішаній моді у випадку неперекривних тріщин і по моді I для перекривних тріщин. Порівняння розрахункових даних з експериментальними підтверджує високу точність і ефективність запропонованого чисельного методу моделювання росту тріщин.

1. H. H. Einstein, D. Veneziano, G. B. Baecher, and K. J. O'Reilly, "The effect of discontinuity persistence on rock slope stability," Int. J. Rock Mech. Min. Sci. Geomech. Abstr., 20, No. 5, 227-236 (1983).

2. N. R. Barton, "Review of a new shear strength criterion for rock joints," Eng. Geol., 7, 287-332 (1973).

3. B. Ladany and G. Archambault, "Simulation of shear behavior of a jointed rock mass," in: Proc. of the 11th Symp. Rock Mechanics (ATME) (1970), pp. 105-125.

4. Z. T. Bieniawski, "Mechanism of brittle fracture of rock. Part II. Experimental studies," Int. J. Rock Mech. Min. Sci. Geomech. Abstr., 4, No. 4, 407-423 (1967).

5. A. Bobet and H. H. Einstein, "Fracture coalescence in rock-type materials under uniaxial and biaxial compression," Int. J. Rock Mech. Min. Sci., 35, 863-888 (1998a).

6. A. Bobet and H. H. Einstein, "Numerical modeling of fracture coalescence in a model rock material," Int. J. Fract., 92, 221-252 (1998b).

7. T. Savilahti, E. Nordlund, and O. Stephansson, "Shear box testing and modeling of joint bridge," in: N. Barton and O. Stephansson (Eds.), Rock Joints (Proc. of Int. Symp. on Rock Joints, June 4-6, 1990, Loen, Norway), Balkema, Rotterdam (1990), pp. 295-300.

8. R. H. C. Wong, W. L. Leung, and S. W. Wang, "Shear strength study on rock-like models containing arrayed open joints," in: D. Elsworth, J. P. Tinucci, and K. A. Heasley (Eds.), Rock Mechanics in the National Interest, Swets \& Zeitlinger Lisse, Leiden (2001), pp. 843-849.

9. C. Gehle and H. K. Kutter, "Breakage and shear behavior of intermittent rock joints," Int. J. Rock Mech. Min. Sci., 40, 687-700 (2003).

10. A. Ghazvinian, M. R. Nikudel, and V. Sarfarazi, "Effect of rock bridge continuity and area on shear behavior of joints," in: Proc. of the 11th ISRM Congress (July 9-13, 2007, Lisbon, Portugal), Lisbon, Portugal (2007).

11. A. Ghazvinian, V. Sarfarazi, W. Schubert, and M. Blumel, "A study of the failure mechanism of planar non-persistent open joints using PFC2D," Rock Mech. Rock Eng., 45, 677-693 (2011). 
12. V. Sarfarazi, A. Ghazvinian, W. Schubert, et al., "Numerical simulation of the process of fracture of echelon rock joints," Rock Mech. Rock Eng., 47, No. 4, 1355-1371 (2013), doi: 10.1007/s00603-013-0450-3.

13. K. Ravi-Chandar and W. G. Knauss, "An experimental investigation into dynamic fracture: III. On steady-state crack propagation and crack branching," Int. J. Fract., 26, 141-154 (1984).

14. H. Horii and S. Nemat-Nasser, "Compression-induced microcrack growth in brittle solids: axial splitting and shear failure," J. Geophys. Res., 90, 3105-3125 (1985).

15. J. F. Huang, G. L. Chen, Y. H. Zhao, and R. Wang, "An experimental study of the strain field development prior to failure of a marble plate under compression," Tectonophysics, 175, 269-284 (1990).

16. P. S. Theocaris and M. Sakellariou, "Crack propagation in brittle materials under compressive stresses studied by caustics," J. Mater. Sci., 26, No. 6, 1640-1646 (1991).

17. R. H. C. Wong, K. T. Chau, C. A. Tang, and P. Lin, "Analysis of crack coalescence in rock-like materials containing three flaws - Part I: experimental approach," Int. J. Rock Mech. Min. Sci., 38, 909-924 (2001).

18. Y. P. Li, L. Z. Chen, and Y. H. Wang, "Experimental research on pre-cracked marble under compression," Int. J. Solids Struct., 42, 2505-2516 (2005).

19. C. H. Park, Coalescence of Frictional Fractures in Rock Materials, Ph.D. Dissertation, Purdue University, West Lafayette, Indiana (2008).

20. S. Q. Yang, Y. H. Dai, L. J. Han, and Z. Q. Jin, "Experimental study on mechanical behavior of brittle marble samples containing different flaws under uniaxial compression," Eng. Fract. Mech., 76, 1833-1845 (2009).

21. C. H. Park and A. Bobet, "Crack coalescence in specimens with open and closed flaws: a comparison," Int. J. Rock Mech. Min. Sci., 46, 819-829 (2009).

22. C. H. Park and A. Bobet, "Crack initiation, propagation and coalescence from frictional flaws in uniaxial compression," Eng. Fract. Mech., 77, 2727-2748 (2010).

23. R. P. Janeiro and H. H. Einstein, "Experimental study of the cracking behavior of specimens containing inclusions (under uniaxial compression)," Int. J. Fract., 164, 83-102 (2010).

24. S. Q. Yang, "Crack coalescence behavior of brittle sandstone samples containing two coplanar fissures in the process of deformation failure," Eng. Fract. Mech., 78, 3059-3081 (2011).

25. P. Cheng-zhi and C. Ping, "Breakage characteristics and its influencing factors of rock-like material with multi-fissures under uniaxial compression," Trans. Nonferrous Met. Soc. China, 22, 185-191 (2012).

26. K. Wallin, "A simple fracture mechanical interpretation of size effects in concrete fracture toughness tests," Eng. Fract. Mech., 99, 18-29 (2013).

27. A. R. Ingraffea and F. E. Heuze, "Finite element models for rock fracture mechanics," Int. J. Num. Anal. Meth. Geomech., 4, 25-43 (1980).

28. M. Fatehi Marji and I. Dehghani, "Kinked crack analysis by a hybridized boundary element/boundary collocation method," Int. J. Solids Struct., 47, 922-933 (2010).

29. M. Fatehi Marji, H. Hosseini-Nasab, and A. H. Kohsary, "A new cubic element formulation of the displacement discontinuity method using three special crack tip elements for crack analysis," JP J. Solids Struct., 1, 61-91 (2007). 
30. C. A. Tang, P. Lin, R. H. C. Wong, and K. T. Chau, "Analysis of crack coalescence in rock-like materials containing three flaws - Part II: Numerical approach," Int. J. Rock Mech. Min. Sci., 38, 925-939 (2001).

31. R. H. C. Wong, C. A Tang, K. T. Chau, and P. Lin, "Splitting failure in brittle rocks containing pre-existing flaws under uniaxial compression," Eng. Fract. Mech., 69, 1853-1871 (2002).

32. F. Erdogan and G. C. Sih, "On the crack extension in plates under plane loading and transverse shear," J. Basic Eng., 85, 519-527 (1963).

33. M. A. Hussian, E. L. Pu, and J. H. Underwood, "Strain energy release rate for a crack under combined mode I and mode II," in: Fracture Analysis, ASTM STP 560 (1974), pp. 2-28.

34. G. C. Sih, "Strain-energy-density factor applied to mixed mode crack problems," Int. J. Fract., 10, 305-321 (1974).

35. B. Shen and O. Stephansson, "Modification of the G-criterion for crack propagation subjected to compression," Eng. Fract. Mech., 47, 177-189 (1994).

36. M. F. Marji, H. Hosseinin-Nasab, and A. H. Kohsary, "On the uses of special crack tip elements in numerical rock fracture mechanics," Int. J. Solids Struct., 43, 16691692 (2006).

37. M. F. Marji, "On the use of power series solution method in the crack analysis of brittle materials by indirect boundary element method," Eng. Fract. Mech., 98, 365382 (2013).

38. H. Haeri, K. Shahriar, M. F. Marji, and P. Moarefvand, "A coupled numericalexperimental study of the breakage process of brittle substances," Arabian J. Geosci., 8, No. 2, 809-825 (2013), doi: 10.1007/s12517-013-1165-1.

39. H. Haeri, K. Shahriar, M. F. Marji, and P. Moarefvand, "On the strength and crack propagation process of the pre-cracked rock-like specimens under uniaxial compression," Strength Mater., 46, No. 1, 140-152 (2014).

40. H. Haeri, M. F. Marji, K. Shahriar, and P. Moarefvand, "On the HDD analysis of micro cracks initiation, propagation and coalescence in brittle substances," Arabian J. Geosci., 8, No. 5, 2841-2852 (2015), doi: 10.1007/s12517-014-1290-5.

41. H. Haeri, K. Shahriar, M. F. Marji, P. Moarefvand, "Investigation of fracturing process of rock-like Brazilian disks containing three parallel cracks under compressive line loading," Strength Mater., 46, No. 3, 404-416 (2014).

42. H. Haeri, K. Shahriar, M. F. Marji, P. Moarefvand, "Simulating the effect of disc erosion in TBM disc cutters by a semi-infinite DDM," Arabian J. Geosci., 8, No. 6, (2014), doi: 10.1007/s12517-014-1489-5.

43. J. T. Chen and H. K. Hong, "Review of dual boundary elements methods with emphasis on hypersingular integrals and divergent series," Appl. Mech. Rev., 52, 17-33 (1999).

44. M. H. Aliabadi, Fracture of Rocks, Computational Mechanics Publications, Southampton, UK (1998).

45. Q. Rao, Z. Sun, O. Stephansson, et al., "Shear fracture (mode II) of brittle rock," Int. J. Rock Mech. Min. Sci., 40, 355-375 (2003).

46. S. Kahraman and R. Altindag, "A brittleness index to estimate fracture toughness," Int. J. Rock Mech. Min. Sci., 41, 343-348 (2004).

47. K. J. Shou and S. L. Crouch, "A higher order displacement discontinuity method for analysis of crack problems," Int. J. Rock Mech. Min. Sci. Geomech. Abstr., 32, 49-55 (1995). 
48. S. L. Crouch, Analysis of Stresses and Displacements around Underground Excavations: An Application of the Displacement Discontinuity Method, University of Minnesota Geomechanics Report, Minneapolis, Minnesota (1967).

49. H. Guo, N. I. Aziz, and R. A. Schmidt, "Linear elastic crack tip modeling by displacement discontinuity method," Eng. Fract. Mech., 36, 933-943 (1990).

50. C. Scavia, "Fracture mechanics approach to stability analysis of crack slopes," Eng. Fract. Mech., 35, 889-910 (1990).

51. M. H. Aliabadi and D. P. Rooke, Numerical Fracture Mechanics, Computational Mechanics Publications, Southampton, UK (1991).

52. M. F. Marji, H. Hosseini-Nasab, and A. Hosseinmorsgedy, "Numerical modeling of the mechanism of crack propagation in rocks under TBM disc cutters," J. Mech. Mater. Struct., 2, 439-457 (2009).

53. G. R. Irwin, "Analysis of stress and strains near the end of a crack traversing a plate," J. Appl. Mech., 24, 361-364 (1957).

Received 20. 07. 2014 